\title{
CXADR wt Allele
}

National Cancer Institute

\section{Source}

National Cancer Institute. CXADR wt Allele. NCI Thesaurus. Code C104700.

Human CXADR wild-type allele is located in the vicinity of $21 \mathrm{q} 21.1$ and is approximately 81

$\mathrm{kb}$ in length. This allele, which encodes coxsackievirus and adenovirus receptor protein, plays a role in both viral infection and tight junction formation. 